\title{
Emission reduction of black carbon and polycyclic aromatic hydrocarbons during COVID-19 pandemic lockdown
}

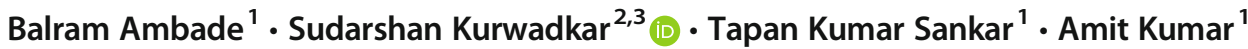 \\ Received: 6 October 2020 / Accepted: 25 February 2021 / Published online: 10 May 2021 \\ (C) The Author(s), under exclusive licence to Springer Nature B.V. 2021
}

\begin{abstract}
The global pandemic COVID-19 necessitated various responses throughout the world, including social distancing, use of mask, and complete lockdown. While these measures helped prevent the community spread of the virus, the resulting environmental benefits of lockdown remained mostly unnoticed. While many studies documented improvements in air quality index, very few have explored the reduction in black carbon $(\mathrm{BC})$ aerosols and polycyclic aromatic hydrocarbons (PAHs) concentrations due to lockdown. In this study, we evaluated the changes in concentrations of $\mathrm{BC}, \mathrm{PAHs}$, and $\mathrm{PM}_{2.5}$ before and during the lockdown period. Our results show that lockdown resulted in a significant reduction in concentrations of these pollutants. The average mass concentration of BC, PAHs, and $\mathrm{PM}_{2.5}$ before the lockdown was $11.71 \pm 3.33 \mu \mathrm{gm}^{-3}, 108.71 \pm 27.77 \mathrm{ngm}^{-3}$, and $147.65 \pm 41.77$ $\mu \mathrm{gm}^{-3}$, respectively. During the lockdown period, the concentration of BC, PAHs, and $\mathrm{PM}_{2.5}$ was $2.46 \pm 0.95 \mu \mathrm{gm}^{-3}, 23.19 \pm$ $11.21 \mathrm{ngm}^{-3}$, and $50.31 \pm 11.95 \mathrm{\mu gm}^{-3}$, respectively. The diagnostic ratio analysis for source apportionment showed changes in the emission sources before and during the lockdown. The primary sources of PAHs emissions before the lockdown were biomass, coal combustion, and vehicular traffic, while during the lockdown, PAHs emissions were primarily from the combustion of biomass and coal. Similarly, before the lockdown, the BC mass concentrations came from fossil-fuel and wood-burning, while during the lockdown period, most of the BC mass concentration came from wood-burning. Human health risk assessment demonstrated a significant reduction in risk due to inhalation of PAHs and BC-contaminated air.
\end{abstract}

Keywords COVID-19 · Black carbon · PAHs · Aethalometer · Emission sources $\cdot$ Backward trajectory $\cdot$ Health risk assessment

\section{Introduction}

Atmospheric aerosols, including black carbon (BC) aerosol and polycyclic aromatic hydrocarbons (PAHs), can pose an adverse risk to human health. These aerosols are also major contributors to $\mathrm{PM}_{2.5}$ particulates in the environment. $\mathrm{BC}$ mass concentration sources are of either natural or anthropogenic origin. Primary natural processes include forest fires, and volcanic eruptions, while the primary anthropogenic activities include domestic uses,

Sudarshan Kurwadkar

skurwadkar@fullerton.edu

1 Department of Chemistry, National Institute of Technology, Jamshedpur, Jharkhand 831014, India

2 Department of Civil and Environmental Engineering, California State University, Fullerton, 800 N. State College Blvd, Fullerton, CA, USA

3 Groundwater Characterization and Remediation Division, U. S. Environmental Protection Agency, 919 Kerr Research Dr., Ada, Oklahoma 74820, USA including the burning of fossil fuel, biomass burning for agriculture, and vehicular movements. Among these, fossil fuel and wood-burning are the most predominant sources. Compared to the presence of centuries of atmospheric $\mathrm{CO}_{2}, \mathrm{BC}$ has a very short atmospheric lifetime (Kopp and Mauzerall 2010; Grieshop et al. 2009; Ramanathan and Carmichael 2008). BC's physical characteristics, such as its intense black/dark color, can easily absorb visible light and heat (Cachier 1995; Hansen et al. 1984). Studies have shown the direct effect of this process in the high-altitude Himalayan-Tibetan region, where the heating effect was attributed to BC (Lau et al. 2010). The atmospheric impact of $\mathrm{BC}$ emission can be direct as well as indirect. For example, $\mathrm{BC}$ absorbs atmospheric water molecules (hygroscopic) and deposit them on the buildings and metal surfaces. It also exhibits optical properties like the scattering of light (He et al. 2015; Khalizov et al. 2009; Zhang et al. 2008).

A perusal of literature suggests that, in the year 2000, Asia was one of the most significant contributors to BC emissions (Ohara et al. 2007; Streets et al. 2003). BC emission has been on the rise because of economic growth, industrialization, urbanization, energy demands, uncontrolled agricultural 
waste burning, peat fire, and forest fires in south and east Asian regions (Chen et al. 2017; Rastogi et al. 2016; Vadrevu et al. 2015). According to one estimate, approximately $40 \%$ of $\mathrm{BC}$ emissions attributed to open biomass burning, $40 \%$ to fossil fuel burning, and the remaining $20 \%$ to biofuel burning (Ramanathan and Carmichael 2008). Global distribution and emission of $\mathrm{BC}$ levels play a critical role in preserving a healthy lifestyle (He et al. 2016; Huang et al. 2020).

The molecular structure of PAHs consists of two to seven fused aromatic rings. They are emitted from natural as well as anthropogenic processes. In the atmosphere, primary anthropogenic sources of PAHs are biomass burning, coal combustion, petroleum, coke, and metal production (Zhang and Tao 2008), while natural sources of PAHs are forest fire and volcanic eruption fires (Baek et al. 1991; Xu et al. 2006). In the atmosphere, the primary source of PAHs is vehicular emission (Bull 2003; Liu et al. 2006; Wang et al. 2007; Mostert et al. 2010) although PAHs are also emitted from industrial activities, especially during energy production and incomplete burning of carbonaceous materials (Xu et al. 2006; Cristale et al. 2012). Most PAHs (around 95\%) have a size below $3 \mu \mathrm{m}$, and as such, they can be easily transported over long distances (Venkataraman et al. 1994). During the last few decades, the occurrence, fate, and distribution of PAHs in the environment have raised serious concerns because of their carcinogenic, teratogenic, and mutagenic properties (Boeuf et al. 2016). Like many aromatic compounds, PAHs' occurrence in the atmosphere poses a serious threat to human health (IARC 1984; Di-Toro et al. 2000; Arey and Atkinson 2003).

Nowadays, almost all countries (developed and developing countries alike) are affected by the coronavirus pandemic (COVID-19). In China, the metropolitan city of Wuhan, a sudden increase in pneumonia cases were reported in December 2019. These cases were attributed to the infections caused by the novel COVID-19 (Wu et al. 2020; Li et al. 2020). Incidentally, Wuhan city also had the first confirmed case of COVID-19 (Huang et al. 2020) followed by SARS$\mathrm{CoV}-2$ (severe acute respiratory syndrome coronavirus) in Spain (Saglietto et al. 2020). After that, the number of infected persons increased rapidly with a short doubling time, and within few months, it became a global pandemic (World Health Organization 2020a, b; CDC 2020; Chan et al. 2020). Considering these widely reported cases of COVID19, the Government of India announced a nationwide lockdown. The lockdown was planned in a phase-wise manner, with Phase I started on March 25th to April 14th, 2020, and lasted for 21 days. Phase I was the strict lockdown phase. The Government of India ordered a complete shutdown of all industrial complexes, factories, educational institutes, and local markets. During this phase, the government put a strict restriction on large public gatherings in places of worship, hotels, restaurants, and shopping malls that impacted residential mobility. Phase II was a continuation of Phase I and lasted for
19 days, ending on May 3rd, 2020. During Phase II, some industries in rural areas were allowed to open to relieve the distress caused by the lockdown. The government allowed the resumption of farm activities and construction of residential buildings and roadways on a limited scale. Phase III \& IV started on May 4th to May 31st, 2020 and lasted for 14 days. During these phases, considerable relaxation was granted in areas with a lower incidence of COVID-19 cases. While many countries worldwide suffered human casualties, better environmental prospects were observed an overall improvement in air quality and reduced emissions of $\mathrm{BC}, \mathrm{PAHs}$, and $\mathrm{PM}_{2.5}$. While many studies reported improvement in air quality (Agarwal et al. 2020; Anil and Alagha 2020; Gautam 2020; Islam et al. 2020; Panda et al. 2020; Sharma et al. 2020; Singh and Chauhan 2020), none have explored the reduction in profile of BC and PAHs because of lockdown. This study presents the monitoring results of BC, PAHs, and PM2.5 particulates before and during the phased lockdown in one of the major industrial cities in northeastern India.

\section{Data collection and methodology}

\section{Description of study area}

Sampling was conducted in Jamshedpur city $\left(22080^{\prime} \mathrm{N}\right.$ Longitude and $86020^{\prime} \mathrm{E}$ Latitude) in the southern part of the Jharkhand state of the eastern part of India. The city is spread over the Chota Nagpur Plateau (CNP) region, covering a total area of around $6500 \mathrm{~km}^{2}$. Jamshedpur city is surrounded by dense forest and greenery of Dalma hills and is known as India's iron city. The total population of Jamshedpur City is approximately 1.3 million (Census of 2011), and the population density is around 6400 people per $\mathrm{km}^{2}$. The CNP has major industrial conglomerates, including TATA Iron and Steel Company (TISCO), TATA motors, cement and chemical industries, power plants, and plastic industries. More than 1000 industries are currently operating in Adityapur under Adityapur Industrial Development Authority (AIDA). The AIDA is one of the largest industrial development authorities in east India. There are many large, medium, and small-scale industries are operating under AIDA. Besides the industrial hub, the highway network is also the primary source of emissions of various atmospheric pollutants. This area may be affected by $\mathrm{BC}, \mathrm{PAHs}$, and $\mathrm{PM}_{2.5}$ aerosols. Industrial burning of coal, dung cake, wood, and high traffic emissions have been the primary sources of atmospheric pollution in this region. In this study, emissions of BC, $\mathrm{PAHs}$, and $\mathrm{PM}_{2.5}$ aerosols were monitored before (from January 3rd to March 23rd) and during the lockdown (from April 1st to June 14th 2020).

During the sampling event, the samplers were deployed above the chemistry department building in the National 
Institute of Technology, Jamshedpur (NIT J). The sampling site map is displayed in Fig. 1. The monthly metrological parameter of study areas such as temperature $\left({ }^{\circ} \mathrm{F}\right)$, wind speed (mph), and humidity (\%) in the study area (Table 1) was collected from https://www.worldweatheronline.com. Besides the measurements obtained from the satellite study, additional fieldwork was undertaken to determine the $\mathrm{BC}$ mass concentrations. The data obtained from the satellite study was coarse and included large areas, while the fieldwork was focused on the target study area of Jamshedpur City, Eastern India.

\section{Measurement of $\mathrm{PM}_{2.5}$ and PAHs concentrations}

The sampling regime mainly consists of monitoring $\mathrm{PM}_{2.5}$ and PAHs concentrations once a week on weekdays and weekends before (from 3rd January to 2nd March 2020) and during the lockdown (from 1st April to 14th June 2020). Series of samplers were deployed on the roof of the chemistry department building at NIT-J. A mini volume sampler (Envirotech Model APM 550) operated at a constant flow rate of $16.5 \mathrm{~L} / \mathrm{min}$ was used for sampling. A 47-mm PTFE filter (Merck, Catalog number PM2547050) was used to collect particulate associated PAHs during the sampling campaign. Before sampling, the filter was kept in a desiccator and weighed before and after the sampling to determine the weight of the particulate using a single pan-top loading digital weight balance (VWR, Model no: VWR1611-2263: with Weighing chamber $\mathrm{L} \times \mathrm{W} \times \mathrm{H}: 162 \times 171 \times 225 \mathrm{~mm})$. The filter was stored in the culture box and kept in the refrigerator at or below $40{ }^{\circ} \mathrm{C}$ until analysis. Background contamination was checked using operational blanks (unexposed filters), which were processed concurrently with field samples.

A total of 16 priority USEPA-PAHs were extracted by Soxhlet extraction. The filter was carefully cut into two pieces to avoid dust loss and kept into 200-ml distillation vessels for $10 \mathrm{~h}$ using dichloromethane (DCM) solvent. The extraction thimble is initially lowered into the solvent. The extraction process was efficient and showed a more than $97 \%$ recovery rate. After extractions, the extracted volume was reduced to $10 \mathrm{ml}$ by a rotatory evaporator. The extracted DCM was condensed in a chiller. The solvent was boiled to reduce the total extraction time, and the evaporated solvent condensed quickly for reuse. This process has significantly reduced the amount of solvent required. The extract was purified using sodium sulfate-silica gel column (glass column of $30 \mathrm{~cm}$ long and $3-\mathrm{cm}$ diameter). The purified extract was reduced to 1-2 $\mathrm{ml}$ by $99.9 \%$ pure nitrogen gas and quantified by advanced gas chromatography (GC-FID, Agilent 7890B) coupled with flame ionization detector (FID) equipped with capillary column HP- 5MS $(30 \mathrm{~m} \times 0.25 \mathrm{~mm}$ i.d $\times$ $0.25 \mu \mathrm{m})$. In splitless mode, $1 \mu \mathrm{l}$ of each sample was injected. The nitrogen (carrier gas) gas flow rate was maintained at $2 \mathrm{ml} \mathrm{min}{ }^{-1}$. The oven temperature ramped from $600{ }^{\circ} \mathrm{C}$ for $3 \mathrm{~min}$ and increased up to $3200{ }^{\circ} \mathrm{C}$ at the rate of $50{ }^{\circ} \mathrm{C} \mathrm{min}{ }^{-1}$ and remained constant for the next $20 \mathrm{~min}$. According to the peak area of spectra and retention time, the 16 USEPA priority PAHs concentrations were quantified. The laboratory blank and field blank samples were extracted and analyzed in the same way as field samples. No PAHs compounds were detected in blank samples, thereby confirming that no crosscontamination of samples occurred.
Fig. 1 Satellite aerial view (Google Earth) of the sampling area at National Institute Technology, Jamshedpur (NIT J)

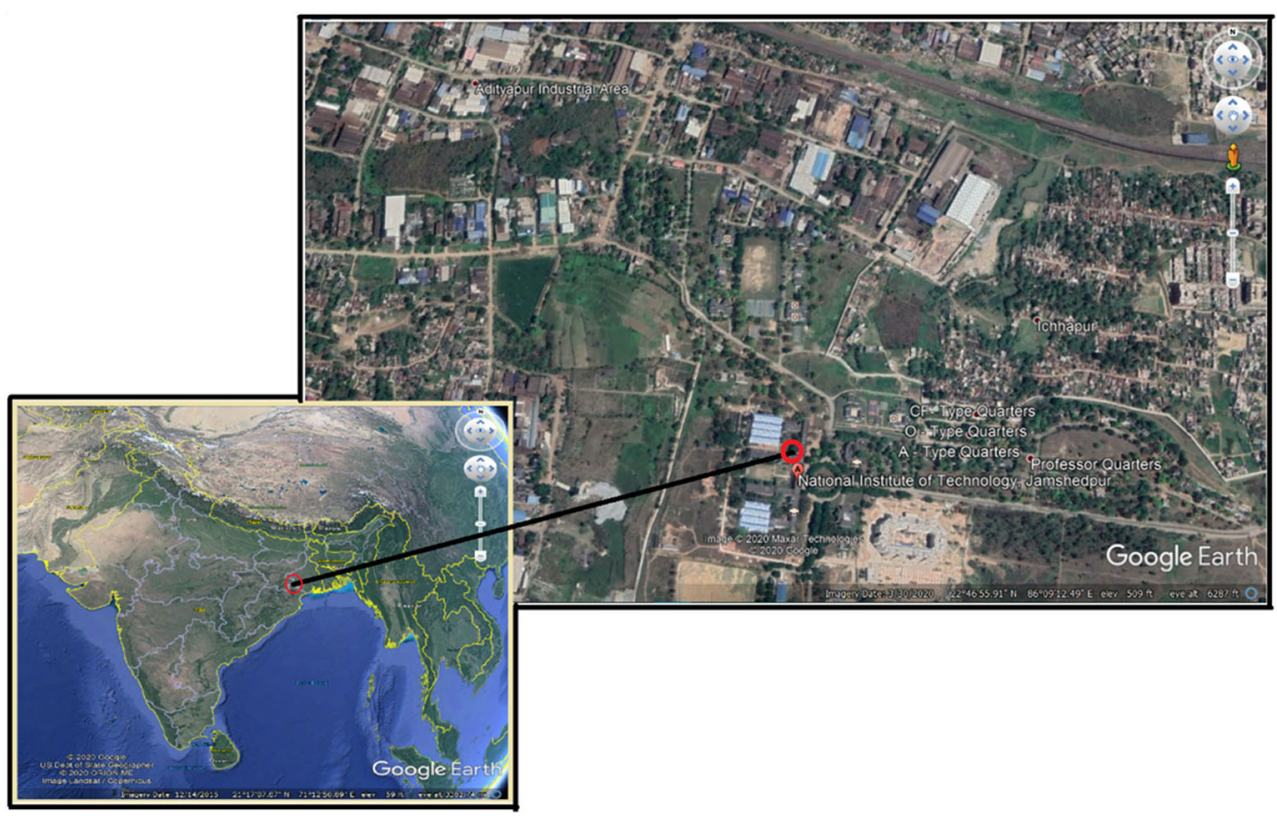


Table 1 Meteorological parameter data, $\mathrm{PM}_{2.5}$, and $\mathrm{BC}$ concentration of before lockdown and during lockdown

\begin{tabular}{|c|c|c|c|c|c|c|c|c|c|c|c|c|}
\hline \multirow[t]{3}{*}{ Parameters } & \multicolumn{6}{|c|}{ Before lockdown } & \multicolumn{6}{|c|}{ During lockdown } \\
\hline & \multicolumn{2}{|l|}{ Jan } & \multicolumn{2}{|l|}{ Feb } & \multicolumn{2}{|l|}{ Mar } & \multicolumn{2}{|l|}{ Apr } & \multicolumn{2}{|l|}{ May } & \multicolumn{2}{|l|}{ Jun } \\
\hline & Mean & SD & Mean & SD & Mean & SD & Mean & SD & Mean & $\mathrm{SD}$ & Mean & $\mathrm{SD}$ \\
\hline Temperature $\left({ }^{\circ} \mathrm{C}\right)$ & 19.3 & 1.93 & 20.53 & 2.67 & 26.38 & 3.13 & 31.2 & 4.1 & 32 & 3.96 & 31.6 & 3.25 \\
\hline Wind speed (mph) & 2.53 & 0.76 & 2.71 & 0.66 & 2.79 & 0.91 & 4.4 & 0.7 & 4.8 & 0.93 & 4.4 & 0.98 \\
\hline Humidity (\%) & 0.61 & 0.15 & 0.58 & 0.08 & 0.54 & 0.12 & 0.62 & 0.1 & 0.59 & 0.11 & 0.56 & 0.07 \\
\hline $\mathrm{PM}_{2.5}\left(\mu \mathrm{gm}^{-3}\right)$ & 162.7 & 47.4 & 158 & 39.3 & 125.3 & 28.5 & 45.8 & 8.9 & 50.4 & 11.9 & 54.7 & 13.3 \\
\hline $\mathrm{BCA}\left(\mu \mathrm{gm}^{-3}\right)$ & 12.7 & 3.86 & 12.65 & 3.14 & 10.03 & 2.28 & 1.8 & 0.3 & 2.26 & 0.59 & 3.31 & 1.02 \\
\hline
\end{tabular}

\section{Measurement of $\mathrm{BC}$ mass concentrations}

The Aethalometer is one of the best and easiest techniques to measure the $\mathrm{BC}$ mass concentration compared to the other techniques like particle soot absorption photometer, coefficient of haze tape sample, and thermal oxidation/reflectance (Allen et al. 1999). Continuous real-time measurement of BC mass concentrations was performed before and during the lockdown period. An Aethalometer (AE-33, Magee Scientific, USA) was used for analyzing the BC mass. The Aethalometer had seven different wavelengths $370,470,520$, $590,660,880$, and $950 \mathrm{~nm}$. This technique is based on the amount of light attenuated by the filter due to the deposition of BC. In the above technique, atmospheric air is pumped over an inlet at the flow rate (about 5 LPM) through a quartz filter. The standard wavelength for measurement of $\mathrm{BC}$ mass concentration was $880 \mathrm{~nm}$ because BC primarily absorbs the light at this wavelength (other aerosol components have negligible absorption) (Hansen et al. 1984; Weingartner et al. 2003). At the standard wavelength of $880 \mathrm{~nm}$, a light beam from a highintensity light-emitting-diode lamp was transferred through the sample deposited on the filter strip. The measurement of attenuation of the light beam was linearly proportional to the amount of BC deposited on the filter strip. The measurements were made at every 5 -min interval.

\section{Source apportionment of BC and PAHs}

The $\mathrm{BC}$ primarily results from incomplete combustions of biofuel and atmospheric burning of fossil fuels (Bond et al. 2013; Petzold et al. 2013). While many researchers have proposed various methods to determine the source apportionment of $\mathrm{BC}$, of these some conventional methods used for determining the source allocation of $\mathrm{BC}$ are chemical mass balance (CMB; Favez et al. 2010), the macro-tracer method (Larsen et al. 2012), the Aethalometer model (Fuller et al. 2014; Sciare et al. 2011), the radiocarbon method (Zhang et al. 2015), positive matrix factorization (Florou et al. 2017), principal component analysis (Thepnuan et al. 2019), and other specialized models (Briggs and Long 2016; Belis et al. 2013) have gained widespread acceptance. In this study, we used the handy Aethalometer model for source apportionment. Although this model identifies fewer source-categories (e.g., traffic emission and wood-burning), it only requires a different-wavelength light absorption dataset (Zotter et al. 2017). We also describe the fire count data and air backward trajectory to analyze the source apportionment of BC mass concentrations, PAHs, and $\mathrm{PM}_{2.5}$. To distinguish between sources of $\mathrm{BC}$ mass concentrations of local emissions at Jamshedpur, we have calculated the percent difference of $\mathrm{BC}$ measured at two different wavelengths $\mathrm{BC} 370$ and $\mathrm{BC} 880$.

$\left(\mathrm{BC}_{370}-\mathrm{BC}_{880}\right) / \mathrm{BC}_{880}$

If the fractional $\mathrm{BC}$ values are negative, then it suggests that $\mathrm{BC}$ emission originated from fossil fuel combustion (diesel and petrol) (Herich et al. 2011). On the other hand, the fractional $\mathrm{BC}$ values are positive; then, it suggests that $\mathrm{BC}$ emission originated from wood burning (forest fire, residential burning of coal, and dry leaf) (Wang et al. 2011). From the diagnostic ratio analysis, we can determine the different sources of PAHs. For diagnostic ratio analysis, the traffic, industrial, and biomass, and coal-burning sources were analyzed.

\section{Human health risk evaluation for BC}

Many studies have demonstrated that exposure to $\mathrm{BC}$ and resulting human health consequences is almost identical to passive smoking (Muller and Muller 2013; van der Zee et al. 2016; Wu et al. 2018). Many similarities exist between exposure to $\mathrm{BC}$ and smoking and resulting in human health impact. Both have similar exposure routes (inhalation), similar health risks, and spontaneous atmospheric exposure (Van der Zee et al. 2016). Due to its smaller particulate size, BC aerosols are directly inhaled from the proximal local or regional sources, including inhalation of environmental tobacco smoke (Ev.TS). Chronic exposure to $\mathrm{BC}$ may pose an adverse risk to 
human health, including carcinogenic and non-carcinogenic risks (De Prins et al. 2014; Niranjan and Thakur 2017; Magalhaes et al. 2018). In this study, we have calculated the health risks associated with atmospheric $\mathrm{BC}$ exposure to local inhabitants before and during the lockdown period. Children and adults were considered as a potential representative receptor chronically exposed to airborne BC. The amount of mass of $\mathrm{BC}$ inhaled by this population is compared with the amount of mass inhaled because of passive cigarette smoking. Van der Zee et al. (2016) developed a risk evaluation method specifically for exposure to Ev.TS. In this method, the authors used Ev.TS to estimate BC's health risk for four different health conditions. The population with low birth weight (LBWt.), percentage lung function decrement of school-aged children (PLFDSC), cardiovascular mortality (CvM), and lung cancer (LC) were considered for estimating the health risk resulting from $\mathrm{BC}$. All four health issues are noticeable by associating BC pollution and Ev.TS exposure (Kelly and Fussell 2015; WHO (World Health Organization) 2014; Oberg et al. 2010). For each health condition, the relative risk due to exposure to $\mathrm{BC}$ and Ev.TS can be calculated. The relative risk describes the relationship between exposure Ev.TS and BC (WHO (World Health Organization) 2003; Rothman et al. 2008; Van der zee et al. 2016). The contact between a specified change in $\mathrm{BC}$ concentration and health risk issue was characterized by the meta-analysis of recorded concentration-response functions (CRFs). For a given health

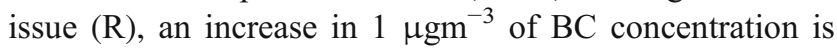
equivalent to the number of passively smoked cigarettes (PSC) (Van der Zee et al. 2016). Therefore, $\mathrm{R}$ is written as:

$R=\left[\ln \left(\mathrm{RR}_{\mathrm{BC}}\right) / \Delta_{\mathrm{Conc}}\right] /\left[\ln \left(\mathrm{RR}_{\mathrm{EV} \text {.TS }}\right) /\right.$ assumed number of PSC $]$

here,

$\left[\ln \left(\mathrm{RR}_{\mathrm{BC}}\right) / \Delta_{\mathrm{Conc}}\right]$

$\left[\ln \left(\mathrm{RR}_{\mathrm{ETS}}\right) /\right.$ assumed number of PSC]

$\mathrm{RR}_{\mathrm{BC}}$

$\mathrm{RR}_{\mathrm{EV} . \mathrm{TS}}$ the resultant risks for change in $\Delta_{\text {Concentration }}$ (i.e., $1 \mu \mathrm{g} \mathrm{m}^{-3}$ ) of BC. the resultant risks of Ev.TS exposure for the assumed number of PSC per day.

$\mathrm{RR}$ of $\mathrm{BC}$ with respect to a health issue.

RR of EV.TS with respect to a health issue.

The value of $\mathrm{RR}_{\mathrm{BC}}$ and $\mathrm{RR}$ for Ev.TS are taken from Pani et al. (2020) and Van der Zee et al. (2016). In the case of PLFDSC, the assumed number of PSC per day is 9. For a child of a non-smoking mother, the assumed number of PSC per day is 7 for CVM and LC, and the same value was assumed for adults with the risk of LBWt (Van der Zee et al. 2016). The equivalent numbers of PSC per day (i.e., NPSC: passive cigarette-equivalence) were estimated using the following formula:

$N_{\text {PSC }}=R \times \Delta \mathrm{BC}$

and

$\Delta \mathrm{BC}=\left[\left(\mathrm{BC}_{\mathrm{obs}}\right)-\left(\mathrm{BC}_{\mathrm{bac}}\right)\right]$

where,

$\mathrm{BC}_{\mathrm{obs}}$ Observed $\mathrm{BC}$ concentration,

$\mathrm{BC}_{\mathrm{bac}}$ Background $\mathrm{BC}$ concentration

In this research, we focused on health risk estimates of $\mathrm{BC}$ pollution but did not evaluate the overall concern regarding the onset of disease due to $\mathrm{BC}$ pollution or Ev.TS exposure. The values of $R R_{B C}$ and $R R_{E v . T S}$ are derived from thorough, systematic reviews and can be summarized to implement the relevant health risk estimates. Our evaluations are based entirely on the assumptions, including the study conducted by Van der Zee et al. (2016), i.e., 14 daily cigarette consumption as per WHO assessment for smokers in the USA and NorthWest Europe. As such, the health risk estimate provided in this study has some limitations.

\section{Human health risk evaluation for PAHs}

Exposure to PAHs through various routes and pathways poses an adverse risk to human health. The toxicity of various forms of PAHs differs significantly; thus, the toxicity equivalent factors (TEF) were established for each specific forms of PAHs. Using these TEFs, toxic equivalency was determined to evaluate the exposure to PAHs (Yu et al. 2008; Yang et al. 2007). The toxic equivalent factors for all PAHs were determined by using the cancer risk of all PAHs relative to the cancer risk of BaP. Equation. 4 was used for estimating the toxic equivalent, which is a simple multiplication of the concentration of each carcinogenic PAHs and their respective TEFs.

$\mathrm{TEQ}=\sum \mathrm{Ci} \times \mathrm{TEFi}$

where, Ci represents the concentration of individual PAHs, and TEFi represents the toxic equivalency factor value (Nisbet and Lagoy 1992). Since the toxic equivalent factors were based on the cancer risk relative to $\mathrm{BaP}$, the resulting TEQs were 1 value for $\mathrm{BaP}$ and $\mathrm{DBahA} ; 0.1$ value for $\mathrm{BaA}$, $\mathrm{BkF}$, and IcP; 0.01 value for $\mathrm{Chr}$, Ant, and $\mathrm{B}$ (ghi)P; and 0.01 for Phe, Flt, and Pyr. Additionally, the exposure risk due to individual PAHs can be quantitatively calculated by incremental lifetime cancer risk (ILCR) (Peng et al. 2011; U.S. EPA 1991; Chen and Liao 2006). To calculate the ILCR, lifetime average daily dose (LADD) of PAHs for children 
(age six years) and adults (age 70 years) were determined. The LADD indicates the mass of PAHs inhaled/ingested by the chronically exposed population per $\mathrm{kg}$ of body weight per day over their lifetime. The LADD only establishes the dose an individual inhales/ingest and does not necessarily indicate the adverse health risk. To quantify the risk, the LADD is multiplied by the respective slope factors (inhalation/ingestion/dermal). Equations 5 and 6 were used for quantifying the ILCR.

$$
\begin{aligned}
& \operatorname{LADD}\left(\mathrm{mg} \mathrm{kg}^{-1} \mathrm{day}^{-1}\right) \\
& \quad=(\mathrm{Cs} \times \mathrm{IR} \times \mathrm{CF} \times \mathrm{EF} \times \mathrm{ED}) /(\mathrm{BW} \times \mathrm{AT}) \\
& \mathrm{ILCR}=\mathrm{LADD} \times \mathrm{CSF}
\end{aligned}
$$

where,

Cs is the sum of the converted airborne particulate $\left(\mathrm{ng} / \mathrm{m}^{3}\right)$ concentration of PAHs based on TEQ value.

IR is the air inhalation rate $\left(\mathrm{m}^{3} /\right.$ day)

$\mathrm{CF}$ represents the unit conversion factor $\left(1 \times 10^{-6} \mathrm{mg} / \mathrm{kg}\right)$

$\mathrm{EF}$ represents the exposure frequency (day/ year)

ED represents the lifetime exposure duration

BW represents the body weight $(\mathrm{kg})$

AT represents the averaging time for carcinogens (days)

CSF represents the inhalation cancer slope factor

(3.85 $\mathrm{mg} \mathrm{kg}^{-1} \mathrm{day}^{-1}$ ) (Peng et al. 2011).

\section{Results and discussion}

\section{Variation in BC mass concentration}

The measurement of BC was obtained from the satellite study through the Giovanni NASA website. These measurements demonstrated that eastern and northeastern India had significantly higher $\mathrm{BC}$ concentrations than the rest of the country. In general, the measured $\mathrm{BC}$ concentrations in the IndoGangetic Plain (IGP) were higher before and during the lockdown period than those measured during the same period in the rest of the country (Fig. 2). The BC mass concentrations in eastern India, before and during the lockdown period,

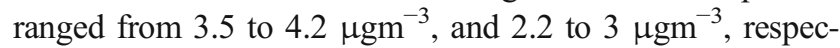
tively (Fig. 2a, b). BC concentration variation is primarily due to the complete lockdown of industries and reduced vehicular traffic during the lockdown period (Fig. 3). The decreasing trend in $\mathrm{BC}$ concentration was noticeable, especially when the lockdown was imposed on the last week of March (Fig. 3).

We monitored the $\mathrm{BC}$ mass concentrations for $12 \mathrm{~h}$ per day before and during the lockdown period. At the study site, the average $\mathrm{BC}$ mass concentrations before and during the lockdown period were approximately $11.71 \pm 3.33 \mathrm{\mu gm}^{-3}$ and $2.46 \pm 0.95 \mathrm{\mu gm}^{-3}$, respectively (Fig. 4b). The monthly (January, February, and March 2020) average concentration

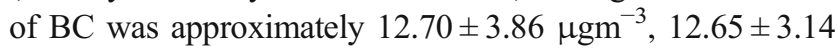
$\mu \mathrm{gm}^{-3}$, and $10.03 \pm 2.28 \mu \mathrm{gm}^{-3}$, respectively. In general, before the lockdown, the $\mathrm{BC}$ concentrations varied from 6.61 to $20.94 \mathrm{\mu gm}^{-3}$. While during the lockdown period, the monthly (April, May, and June 2020) average concentration of BC was approximately $1.80 \pm 0.34{\mu \mathrm{gm}^{-3}}^{-}, 2.26 \pm 0.59 \mathrm{\mu gm}^{-3}$, and $3.31 \pm 1.02{\mu \mathrm{gm}^{-3}}^{-3}$, respectively. In general, the BC concentrations varied from 1.10 to $5.27 \mathrm{\mu gm}^{-3}$. Continuous reduction in $\mathrm{BC}$ mass concentration emission was recorded during the lockdown period due to the complete shutdown of industries, construction activities, and vehicular traffic during lockdown period.

\section{Variation in $\mathrm{PM}_{2.5}$ and PAHs concentrations}

We monitored the $\mathrm{PM}_{2.5}$ concentrations before and during the lockdown period. Throughout the study, variation in $\mathrm{PM}_{2.5}$ concentrations was observed (Fig. 4a). The average $\mathrm{PM}_{2.5}$ concentrations at the study site before and during the lockdown period were $147.65 \pm 41.77 \mathrm{\mu gm}^{-3}$ and $50.31 \pm 11.95$ $\mu \mathrm{gm}^{-3}$, respectively. The monthly average concentrations of $\mathrm{PM}_{2.5}$ for January, February, and March 2020 were approximately $162.74 \pm 47.44{\mu \mathrm{gm}^{-3}}^{-3} 158.09 \pm 39.31{\mu \mathrm{gm}^{-3}}$, and
Fig. 2 Time average map of BC surface mass concentration monthly $0.5 \times 0.625 \mathrm{deg}$. [MERRA-2 Model

M2TMNXAER $v$ 5.12.4] at the two different situations. a Before the lockdown period. b During the lockdown period
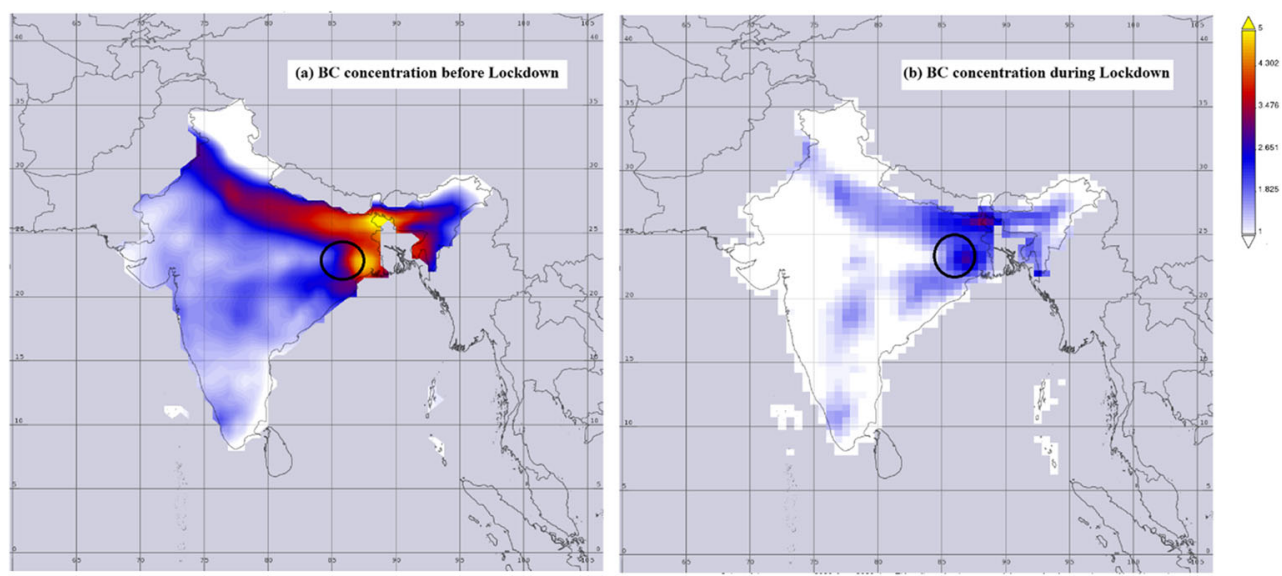
Fig. 3 Daily basis mass concentration of $\mathrm{PM}_{2.5}$ and $\mathrm{BC}$ before and during the lockdown period at NIT J

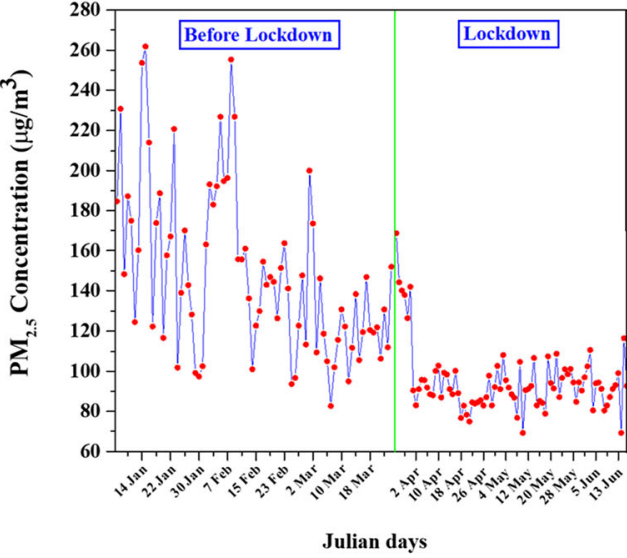

(a)

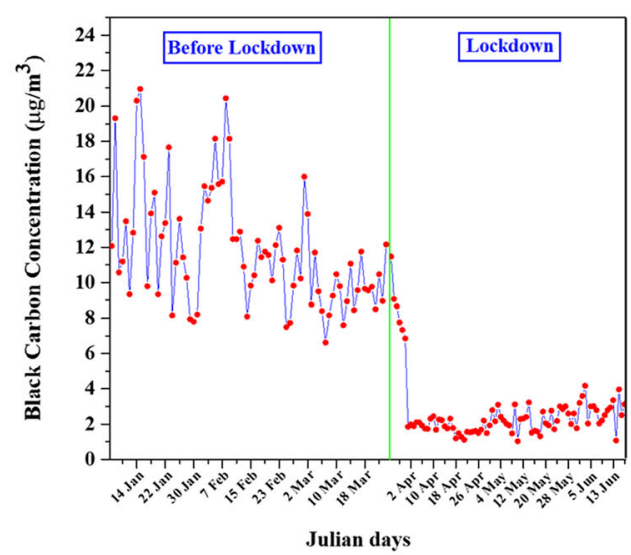

(b)
$125.33 \pm 28.54{\mu \mathrm{gm}^{-3}}^{-3}$, respectively. Before the lockdown, $\mathrm{PM}_{2.5}$ concentrations varied from 82.67 to $261.78 \mathrm{\mu gm}^{-3}$. On the other hand, during the lockdown period, the monthly average concentration of $\mathrm{PM}_{2.5}$ were $45.80 \pm 8.90 \mathrm{\mu gm}^{-3}$, $50.43 \pm 11.93{\mu \mathrm{gm}^{-3}}$, and $54.70 \pm 13.26 \mathrm{\mu gm}^{-3}$ in April, May, and June 2020, respectively. In general, the $\mathrm{PM}_{2.5}$ con-

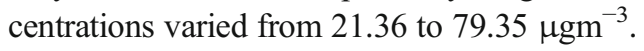

Like $\mathrm{BC}$ and $\mathrm{PM}_{2.5}$ concentrations, PAHs concentrations were also observed during this period. In this study, the sum of 16 PAHs concentrations was analyzed. Variations in PAHs concentrations throughout the study period are shown in Fig. 5. The approximate average PAHs concentrations at the study site before and during the lockdown were $108.71 \pm$ $27.77 \mathrm{ngm}^{-3}$ and $23.19 \pm 11.21 \mathrm{ngm}^{-3}$, respectively. These measurements show that PAHs concentration gradually decreased during the lockdown. Compared to the prelockdown period, approximately one-fifth reduction in emission of PAHs concentrations was recorded during the lockdown period. Before the lockdown, the highest concentrations were recorded for phenanthrene (Phe) $9.23 \pm 2.27 \mathrm{ngm}^{-3}$, while the lowest concentrations were recorded for acenaphthylene (Acy) $4.09 \pm 1.19 \mathrm{ngm}^{-3}$. During lockdown periods, however, the highest concentrations were recorded for benzo[b]fluoranthene $(\mathrm{BbF}) 1.89 \pm 1.42 \mathrm{ngm}^{-3}$, while the lowest concentrations were recorded for benzo[a]pyrene (BaP) $0.68 \pm 0.51 \mathrm{ngm}^{-3}$. Tables 1 and 2 provide the statistical summaries of $\mathrm{BC}$ and $\mathrm{PM}_{2.5}$ mass concentrations and summary results of all 16 PAHs concentrations. High BC, PAHs, and $\mathrm{PM}_{2.5}$ mass concentrations at the study site suggested that the atmosphere is mostly polluted by anthropogenic activities such as coal, wood, and fossil-fuel burning. The regular emission of $\mathrm{BC}, \mathrm{PM}_{2.5}$, and PAHs concentrations at the study site was partly due to industrial and vehicular emissions and partly due to residential burning of coal, wood, biomass, and kerosene. During the lockdown, all anthropogenic activities were at a standstill resulting in reduced emissions of air pollutants in the atmosphere. In summary, the mandatory lockdown due to the COVID-19 pandemic has significantly reduced the atmospheric emissions of $\mathrm{BC}, \mathrm{PAHs}$, and $\mathrm{PM}_{2.5}$.

\section{Backward trajectories analysis}

Backward trajectory analysis demonstrates the transport pathways of air pollutants. It helps determine the direction of airflow and the possible regional sources before pollutants reach the targeted location. Local meteorology, emission, and
Fig. 4 Monthly basis mass concentration with standard deviation of $\mathrm{PM}_{2.5}$ and $\mathrm{BC}$ before and during the lockdown period at NIT J

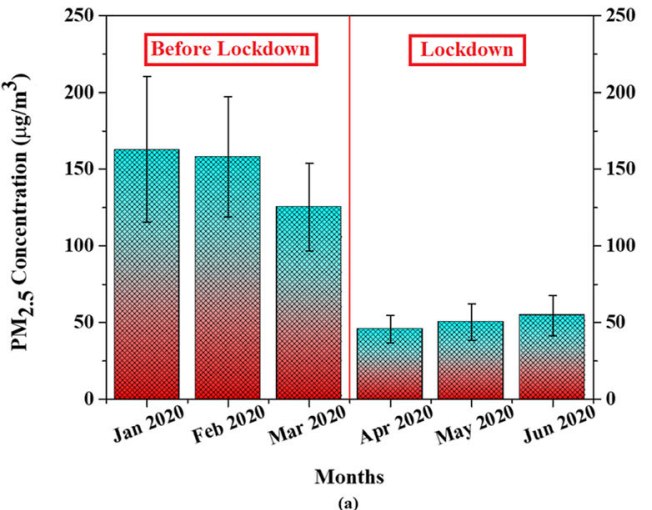

(a)

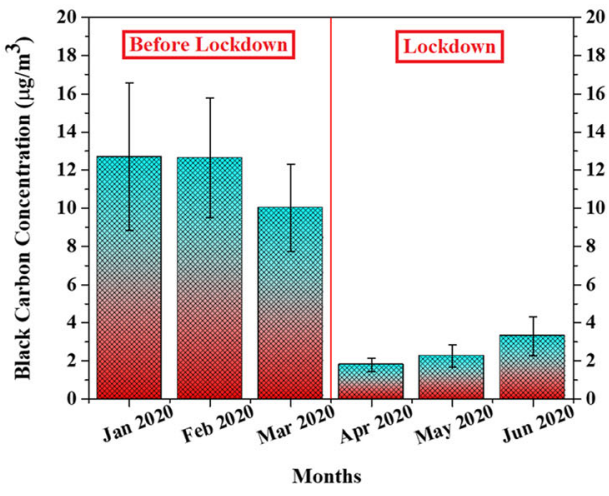

(b) 
Fig. 5 Concentration $\left(\mathrm{ng} / \mathrm{m}^{3}\right)$ of PAHs before and during the lockdown periods at NIT J

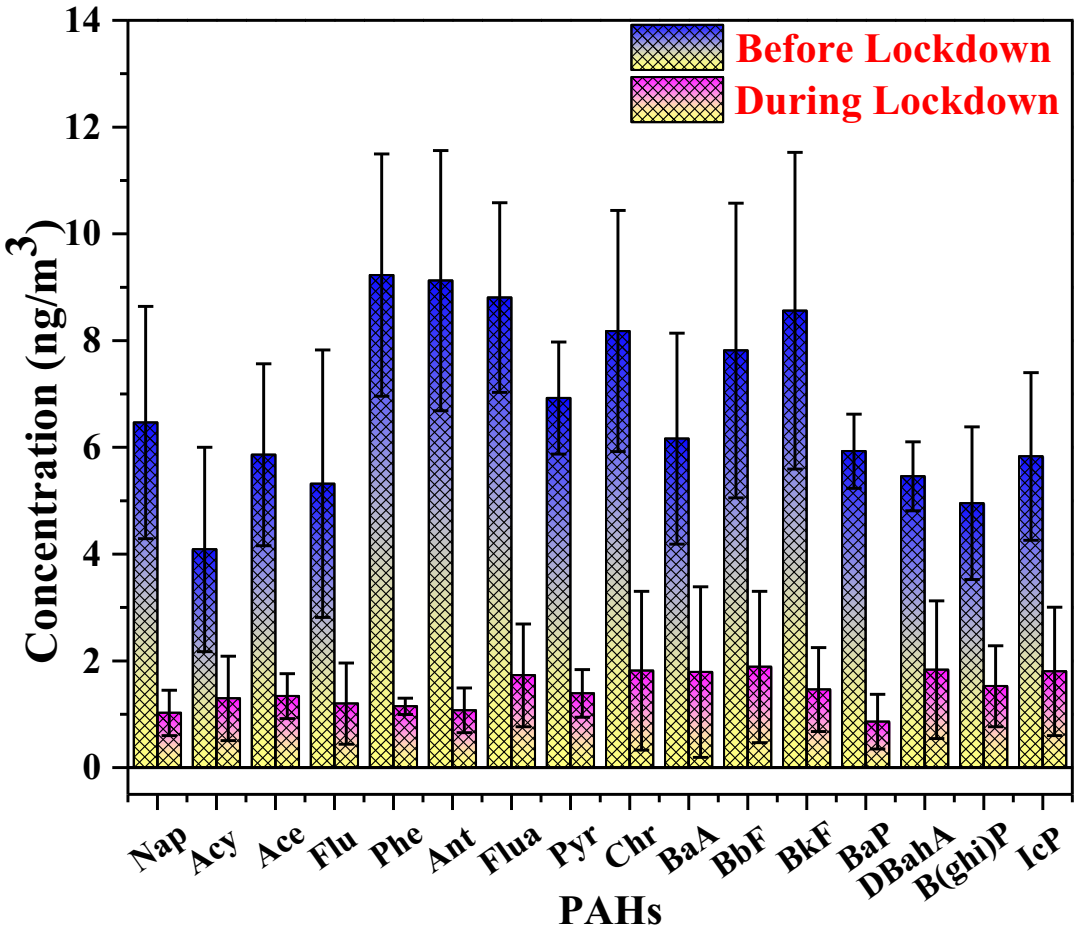

photo-chemistry can play essential roles in concentration variation. The higher concentration level of PAHs and BC at the study site is directly or indirectly linked with the local sources of emissions and long-range transport of pollutants from other countries. We have used 7-day back trajectory data for two different situations (before and during the lockdown) to determine the potential sources. The back trajectory was mapped using an online global environmental dataset program-NCEP (National Centers for Environmental Prediction) Climate Forecast System. The overall trajectories were prepared with the help of Meteorological Data Explorer developed by the Centre for Global Environmental Research
Table 2 The concentration of PAHs before and during lockdown

\begin{tabular}{|c|c|c|c|c|c|c|}
\hline \multirow[t]{2}{*}{ PAHs } & \multirow[t]{2}{*}{ Abbreviation } & \multirow[t]{2}{*}{ No. of rings } & \multicolumn{2}{|c|}{ Before lockdown } & \multicolumn{2}{|c|}{ During lockdown } \\
\hline & & & Mean & SD & Mean & $\mathrm{SD}$ \\
\hline Naphthalene & Nap & 2 & 6.47 & 2.18 & 1.03 & 0.43 \\
\hline Acenaphthylene & Acy & 3 & 4.09 & 1.91 & 1.3 & 0.79 \\
\hline Acenaphthene & Ace & 3 & 5.86 & 1.7 & 1.34 & 0.42 \\
\hline Fluorene & Flu & 3 & 5.32 & 2.51 & 1.2 & 0.76 \\
\hline Phenanthrene & Phe & 3 & 9.23 & 2.27 & 1.15 & 0.15 \\
\hline Anthracene & Ant & 3 & 9.12 & 2.44 & 1.07 & 0.42 \\
\hline Fluoranthene & Flua & 4 & 8.81 & 1.78 & 1.73 & 0.96 \\
\hline Pyrene & Pyr & 4 & 6.92 & 1.05 & 1.39 & 0.45 \\
\hline Chrysene & $\mathrm{Chr}$ & 4 & 8.18 & 2.26 & 1.82 & 1.49 \\
\hline Benzo[a]anthracene & $\mathrm{BaA}$ & 4 & 6.16 & 1.98 & 1.79 & 1.6 \\
\hline Benzo[b]fluoranthene & $\mathrm{BbF}$ & 5 & 7.82 & 2.76 & 1.89 & 1.42 \\
\hline Benzo[k]fluoranthene & $\mathrm{BkF}$ & 5 & 8.56 & 2.97 & 1.46 & 0.79 \\
\hline Benzo[a]pyrene & $\mathrm{BaP}$ & 5 & 5.93 & 0.7 & 0.86 & 0.51 \\
\hline Dibenzo[ah]anthracene & DBahA & 5 & 5.46 & 0.65 & 1.83 & 1.29 \\
\hline Benzo[ghi]perylene & $\mathrm{B}$ (ghi)P & 6 & 4.95 & 1.43 & 1.53 & 0.76 \\
\hline Indeno[123-cd]pyrene & IcP & 6 & 5.83 & 1.57 & 1.8 & 1.2 \\
\hline$\sum \mathrm{PAH}$ & & & 108.71 & 27.77 & 23.19 & 11.21 \\
\hline
\end{tabular}


(CGER), Japan, and Igor software. Backward trajectories are calculated at different heights (altitude) from 0 to $5000 \mathrm{~m}$ using distinct color bands. The fire count data from NASA FIRMS were also incorporated along with back trajectories, as shown in Fig. 6. (https://irms.modaps.eosdis.nasa.gov/data/ download/DL_FIRE_M6_76896.zip). Mean individual trajectories corresponding to before and during the lockdown periods were considered for finalizing the trajectories during these two intervals. According to the back-trajectory analysis, the air mass originated from different sources during different seasons. Before the lockdown period, the airborne particulate matter was transported from northeast India. Maximum air pollutants were originated from the Himalayan region, while some originated from the Bay of Bengal. Interestingly, compared to other regions, the difference in the height of trajectories in these regions is lower. Long-range atmospheric transport was also observed, spanning as far as Southern and Southwestern Asian countries such as Afghanistan, Pakistan, and Iran (Fig. 6a). Maximum air pollutants were originated from Pakistan and Afghanistan. However, the height of trajectories is moderate during the lockdown period (Fig. 6b). During the lockdown period, it was seen that the airborne particulate matter was transported from Northern and Northeastern India. While some particulate matter also originated from the Indian Ocean and the Bay of Bengal.

\section{Source apportionment of BC and PAHs}

Source apportionment analysis is critical for accurately identifying various air pollutants originating from various natural and anthropogenic sources. The technique for analyzing the sources varies with the pollutants' characteristics, even though they may originate from the same sources. For example, BC and PAHs' mass concentration could originate from the same source, yet they have different characterization techniques for source apportionment analysis. The BC measurement technique could determine the sources of $\mathrm{BC}$ mass concentration, while the Aethalometer model can characterize additional source-categories like wood-burning and traffic emissions. In this study, the presence of UV absorbing organic compounds was identified by using $370-\mathrm{nm}$ wavelengths. An analysis of BC measured at $370 \mathrm{~nm}$ (UV) and $880 \mathrm{~nm}$ (near-IR) wavelengths are favorable for the source recognition of BC (Srivastava et al. 2012). In India, coal-burning is a significant energy source that supplies $76 \%$ of the country's requirements. It is the highest contributory source of $\mathrm{BC}$ mass concentration in the atmosphere (SAFAR (System for Air Quality Forecasting and Research) 2010). In this study, source apportionment analysis was conducted before and during the lockdown period. This analysis focuses on differentiating between the BC and PAHs sources originating from woodburning and fossil fuel.

The source apportionment analysis results show that before the lockdown, the contributions of BC and PAHs from fossil fuel and wood burning were approximately the same. However, during the COVID-19 pandemic (during lockdown), the BC and PAHS emissions from wood-burning were as high as those from fossil fuel burning. These changes in emissions sources could be attributed to the significantly reduced movement of vehicles and complete shutdown of industries operating in the study area (Fig. 7). Among the various sources discussed above, biofuel burning and agriculture fires were recognized as the largest BC emitting sources over the Indo-Genetic Basin (IGB) areas (Venkataraman et al. 2006). The concentration of $\mathrm{BC}$ is high before and during the lockdown (Fig. 2). The Himalayan range in this region could have potentially obstructed the wind movement and subsequently impacted the $\mathrm{BC}$ mass flow. Otherwise, it is well-known that BC can be transported over long distances because it is chemically inert, and its fine size makes it easily airborne (Wolff 1981).

\section{Diagnostic ratio analysis (DRA)}

DRA is a widely used technique for source apportionment (Tobiszewski and Namieśnik 2012). The ratios of Flua/(Flua+Pyr), Ant/(Ant+Phe), IcP/(IcP + B(ghi)P), BaA/ $(\mathrm{BaA}+\mathrm{Chr}$ ), and $\mathrm{BaP} / \mathrm{B}$ (ghi)P were used for distinguishing the sources of PAHs in the atmosphere. For example, if the ratio of Flua/(Flua+Pyr) is $<0.1$, it indicates that the source is petrogenic/unburned petroleum, between 0.4 and 0.5 , the
Fig. 6 Seven-day air mass backtrajectories as well as fire count graph on two different situations. a Before the lockdown period. $\mathbf{b}$ During the lockdown period, at altitude level of $500 \mathrm{~m}$ above ground level, over sampling side
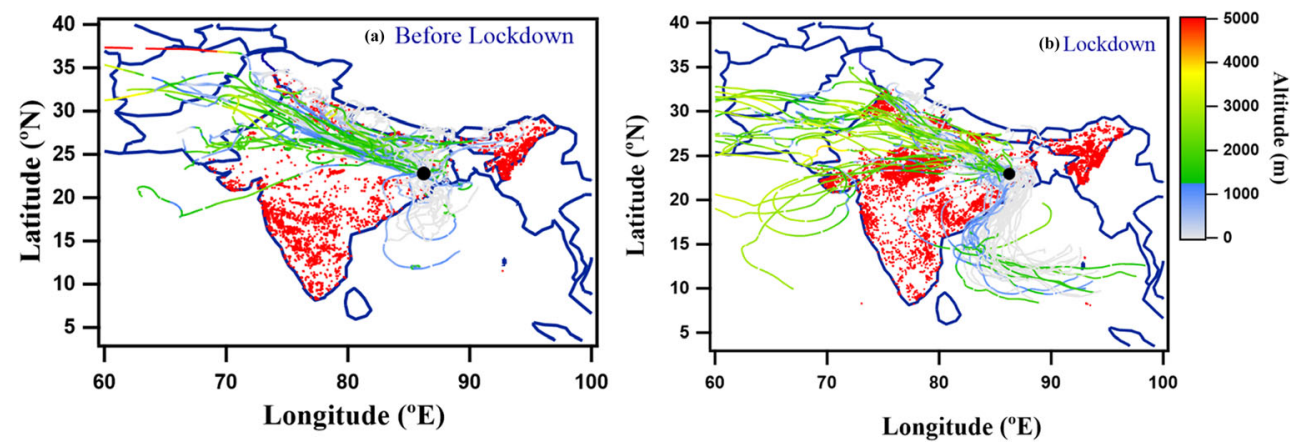
Fig. 7 Fractional contribution of $\mathrm{BC}$ measured at 370 and $880 \mathrm{~nm}$ before and during the lockdown period at NIT J

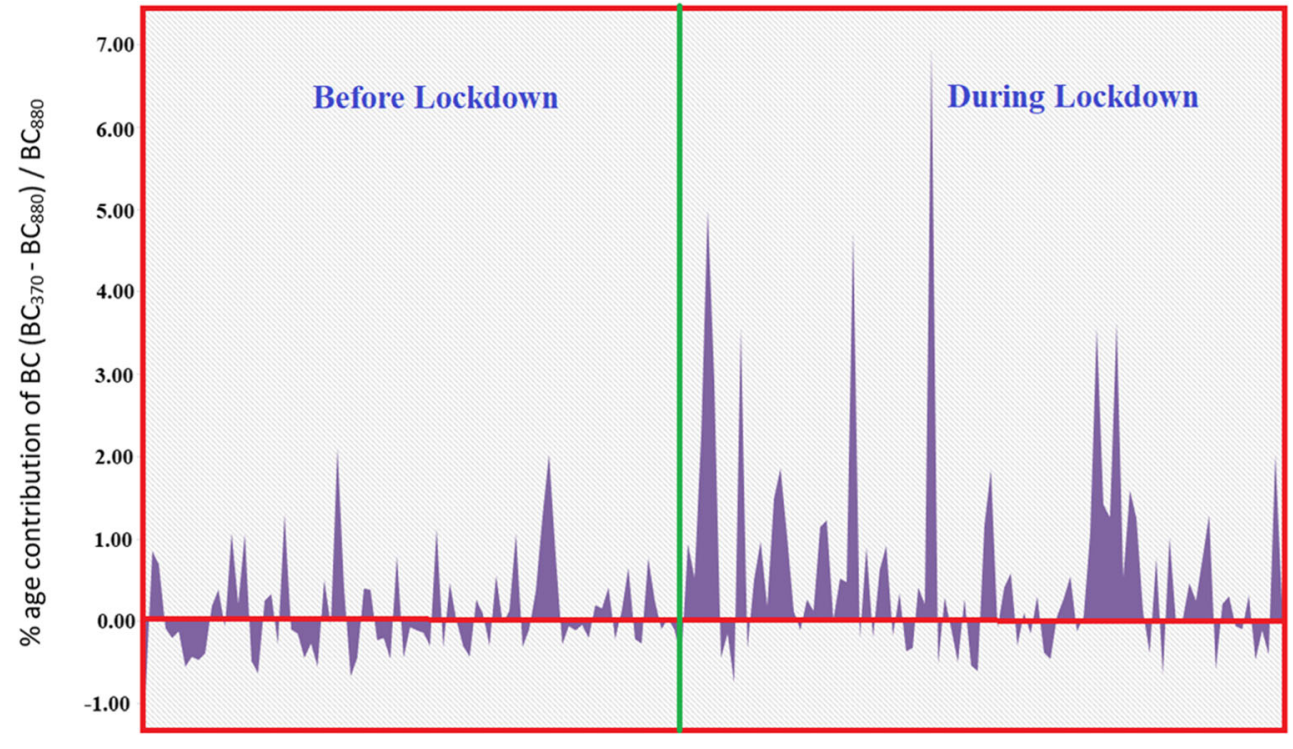

Days (3' January $2020-14^{\text {th }}$ May 2020) source is fossil fuel combustion, and $>0.5$, then the source is biomass and coal combustion (De La Torre-Roche et al. 2009; Yunker et al. 2002). Since the ratios of Flua/(Flua+Pyr) at the study site before and during the lockdown were 0.55 and 0.53 , we inferred that the sources of PAHs at the study site were biomass and coal combustion. Similarly, if the ratio of Ant/ (Ant+Phe) is $<0.1$, it indicates that the source is petrogenic, and if the ratio is $>0.1$, the source is pyrogenic (Pies et al. 2008). Ant/(Ant+Phe) ratio at the study site was 0.50 and 0.46 before and during the lockdown period, respectively, suggesting the pyrogenic source. The $\mathrm{IcP} /(\mathrm{IcP}+\mathrm{B}(\mathrm{ghi}) \mathrm{P})$ ratio is an indicator of petroleum combustion, petrogenic, and biomass coal combustion source. The value of $0.5<$ Ratio $<0.2$ indicates that the PAHs source is petrogenic and biomass combustion. This ratio within the range of $0.2-0.5$ also indicates that PAHs originated from petroleum combustion (Ravindra et al. 2008). The IcP/(IcP $+\mathrm{B}($ ghi)P $)$ ratios for the study site before and during the lockdown period were 0.54 and 0.49 , respectively, suggesting emissions from biomass and coal combustion. The ratio of $\mathrm{BaA} /(\mathrm{BaA}+\mathrm{Chr})$ is an indicator of petrogenic and combustion sources if the value is $0.35<$ Ratio $<0.2$ (Yunker et al. 2002; Tobiszewski and Namieśnik 2012). The $\mathrm{BaA} /(\mathrm{BaA}+\mathrm{Chr})$ ratios for the study site before and during the lockdown period were 0.42 and 0.45 , respectively, suggesting emissions from biomass and coal combustion. $\mathrm{BaP} / \mathrm{B}$ (ghi) $\mathrm{P}$ ratio indicates that the source of $\mathrm{PAHs}$ is from traffic emissions. If this ratio is $<0.6$, it indicates a nontraffic source, but if the ratio is $>0.6$, it indicates the traffic source of emission. $\mathrm{BaP} / \mathrm{B}$ (ghi)P ratio values before and during the lockdown were 1.19 and 0.56 , respectively, suggesting that PAHs originated from a traffic source before lockdown, but during the lockdown, the PAHs originated from non- traffic sources. The summary calculations for the DRA is presented in Table 3. The comprehensive DRA confirmed that biomass and coal combustion and vehicular emissions were primary sources of PAHs before the lockdown period. During the lockdown period, emissions of PAHs primarily arise from the combustion of biomass and coal.

\section{Human health risk assessment for BC and PAHs}

We report the health risk assessment expressed in two different situations, i.e., before the lockdown and during the lockdown period at Jamshedpur city. In the present study, we assumed that BC's daily exposure for the people living in Jamshedpur city was equivalent to the daily mean BC (balance load concerning the background $\mathrm{BC}$ ) level. The summary of human health risk assessment for $\mathrm{BC}$ shows one to one correspondence for PSC between before and during the lockdown period (Table 4). The risk estimates are presented for an increment of $1 \mathrm{\mu gm}^{-3}$ in BC concentration. These increments are generally used to express the relative risks of air pollutants such as BC. The BCbac concentration level was determined as the 1.25th percentile of BCobs concentrations for all the datasets (Rupakheti et al. 2017). The observed concentrations before and during the lockdown period were $7.34 \mu^{-3}{ }^{-3}$ and $1.07 \mathrm{\mu gm}^{-3}$, respectively. Before lockdown, the health risk assessment of $\mathrm{BC}$ concentration was found to be as high as $15.58,7.85,14.06$, and 32.08 passive cigarettes-comparable concerning the risk of CVM, LC, LBWt, and PLEDSC, respectively. During the lockdown, the health risk assessment of BC concentration was significantly lower with 4.92, 2.48, 4.44, and 10.12 passive cigarettes comparable concerning the risk of CVM, LC, LBWt, and PLEDSC, respectively. 
Table 4 The health risk estimates of BC communicated into equivalent numbers of PSC per day with respect to four various health issues

\begin{tabular}{lll}
\hline Parameters & Before lockdown & DuringlLockdown \\
\hline CVM & 15.58 & 4.92 \\
LC & 7.85 & 2.48 \\
LBWt & 14.06 & 4.44 \\
PLEDSC & 32.08 & 10.12
\end{tabular}

$P S C$, passively smoked cigarettes; $C V M$, cardiovascular mortality; $L C$ : lung cancer; $L B W t$ : low birth weight; $P L F D S C$, percentage lung function decrement of school-aged children

The risk assessment demonstrates that the health risk was higher during regular days (before the lockdown) than the health risk during the COVID-19 pandemic (during lockdown). Reduction in overall risk assessment due to exposure to BAC is attributed to mandatory and legally enforced lockdown that resulted in complete closure of all the anthropogenic activities, including industries (small and large), workshops, and transportation services. The complete lockdown has significantly reduced the mass concentration of $\mathrm{BC}$ from all sources.

Additional human health risk analysis of USEPA designated 16 priority PAHs were conducted. The results show that before the lockdown, the highest carcinogenicity was attributed to $\mathrm{BaP}(40.6 \%)$ and DBahA (39\%). During the lockdown period, the carcinogenicity of $\mathrm{BaP}$ was reduced to $32 \%$; however, the carcinogenicity due to DBahA increased to $52 \%$. Furthermore, The LADD values for carcinogenic PAHs for adults were found at $1.44 \times 10^{-6}$ and $4.3 \times 10^{-5} \mathrm{mg} \mathrm{kg}^{-1}$ day $^{-1}$ over the study site before and during the lockdown, respectively. Similarly, for a child, the LADD values were before

Table 5 Health risk assessment due to PAHs exposure to children and adult over the study area

\begin{tabular}{|c|c|c|}
\hline \multirow[t]{2}{*}{ Exposure parameters } & \multicolumn{2}{|c|}{ Exposed population } \\
\hline & Child & Adult \\
\hline Body weight (kg) & 18 & 60 \\
\hline Averaging time (days) & 70 & 70 \\
\hline Inhalation rate ( $\mathrm{m}^{3} /$ days) & 10 & 20 \\
\hline Exposure frequency (days/year) & 365 & 365 \\
\hline Exposure duration (years) & & 24 \\
\hline \multirow[t]{4}{*}{ Lifetime average daily dose ( $\mathrm{mg} / \mathrm{kg}$.day) } & \multicolumn{2}{|c|}{ Before lockdown } \\
\hline & $6 \times 10^{-5}$ & $1.44 \times 10^{-6}$ \\
\hline & \multicolumn{2}{|c|}{ During lockdown } \\
\hline & $1.7 \times 10^{-5}$ & $4.3 \times 10^{-5}$ \\
\hline \multirow[t]{4}{*}{ Incremental lifetime cancer risk } & \multicolumn{2}{|c|}{ Before lockdown } \\
\hline & $6 \times 10^{-5}$ & $1.44 \times 10^{-6}$ \\
\hline & \multicolumn{2}{|c|}{ During lockdown } \\
\hline & $1.7 \times 10^{-5}$ & $1.65 \times 10^{-6}$ \\
\hline
\end{tabular}


and during the lockdown were $6 \times 10^{-5}$ and $1.7 \times$ $10^{-5} \mathrm{mg} \mathrm{kg}^{-1} \mathrm{day}^{-1}$, respectively. Based on LADD values observed for the study site, total ILCR due to inhalation of airborne PAHs for adults before and during the lockdown period were estimated as $5.5 \times 10^{-6}$ and $1.65 \times 10^{-6}$, respectively. Similarly, the ILCR values for children before and during the lockdown were estimated as $2.31 \times 10^{-6}$ and $6.5 \times 10^{-6}$, respectively. The excess lifetime cancer risk (ELCR) was estimated by adding the ILCR values for adults and children. The ELCR values before and during the lockdown period were $7.81 \times 10^{-6}$ and $8.15 \times 10^{-6}$, respectively. These estimated ELCR values were within the acceptable limit $10^{-6}-10^{-4}$ stipulated by the USEPA (United States Environmental Protection Agency 1989). Complete summaries of the health risk assessment of PAHs are presented in Table 5. The result showed that the risk level was acceptable over the study site during and before the lockdown period.

\section{Conclusions}

In this study, we report the spatio-temporal changes in mass concentrations measurement of BC, PAHs, and $\mathrm{PM}_{2.5}$ particulates before and during the lockdown period. The mass concentration of $\mathrm{PM}_{2.5}$ before the lockdown ranged from 82.67 to $261.78 \mu \mathrm{gm}^{-3}$, and during the lock-

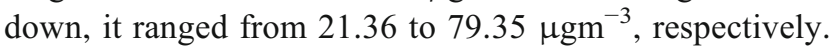
An average $\mathrm{PM}_{2.5}$ mass concentrations before and during the lockdown were recorded as $147.65 \pm 41.77 \mu^{-3} \mathrm{gm}^{-3}$ and $50.31 \pm 11.95{\mu \mathrm{gm}^{-3}}^{-3}$, respectively. These measurements demonstrate that during the lockdown period, a one-third reduction in emissions of $\mathrm{PM}_{2.5}$ occurred. Similar reductions in mass concentrations of $\mathrm{BC}$ is observed with the pre lockdown concentrations ranged from 6.61 to 20.94 $\mathrm{\mu gm}^{-3}$, respectively. While during the lockdown, the mass concentration of $\mathrm{BC}$ ranged from 1.10 to 5.27 $\mu \mathrm{gm}^{-3}$, respectively. The average mass concentrations of $\mathrm{BC}$ before and during the lockdown were $11.71 \pm 3.33$ $\mu \mathrm{gm}^{-3}$ and $2.46 \pm 0.95 \mathrm{\mu gm}^{-3}$, respectively. Approximately $80 \%$ reductions in $\mathrm{BC}$ emission could be attributed to reduced fuel consumption and considerable reduction in other emission sources such as power plants, diesel, and biofuel consumption. Potential uncertainties exist to determine the reduction of $\mathrm{BC}$ levels accurately. For example, the DRA of BC demonstrated that although there is no difference between the release of $\mathrm{BC}$ arising from wood burning and fossil fuel consumption during regular days, during the lockdown, increased emissions from wood burning is observed compared to the emissions from fossil fuel consumptions. Significant reduction in PAHs levels is observed during the lockdown period, with the PAHs mass concentrations before and during the lockdown period were $108.71 \pm 27.77 \mathrm{ngm}^{-3}$ and $23.19 \pm$
$11.21 \mathrm{ngm}^{-3}$, respectively. The diagnostic ratio analysis of PAHs suggests that biomass, coal combustion, and vehicle emission were primary sources of PAHs before the lockdown period. However, during the lockdown period, emissions from the combustion of biomass and coal were major contributors of PAHs. The health risk assessment due to exposure to PAHs before and during the lockdown showed that the ELCR is well within the USEPA's acceptable risk $10^{-6}-10^{-4}$. Even though there was a net reduction in the emission of PAHs, the risk posed by reduced PAHs mass concentration was well within the regulatory limit. A significant reduction in human health risk due to $\mathrm{BC}$ exposure during the lockdown period was observed. The reduced human health risk to $\mathrm{BC}$ could be attributed to the complete shutdown of all industries (small and large), workshops, and transportation activities during the lockdown.

Acknowledgements The authors thank NASA Giovanni, NASA FIRMS (Fire Information for Resource Management System), Fire Archive for fire count data by MODIS (Moderate Resolution Imaging Spectroradiometer) C6. The authors acknowledge Meteorological Data Explorer developed by the Centre for Global Environmental Research (CGER), Japan (METEX, http://db.cger.nies.go.jp/metex/trajectory. $\mathrm{html}$ ) and for providing trajectories used in this research study. The daily mean temperature, rainfall, and relative humidity data for this study were obtained from https://www.worldweatheronline.com.

Funding

The SERB-DST (Science and Engineering Research Board, Department of Science and Technology), Government of India, Sanction Order Number ECR/2017/000597, financially supported this research.

Data availability All the data used in the present study will be made available upon request.

\section{Declarations}

Conflict of interest/Competing interests The authors declare no competing interests.

\section{References}

Agarwal A, Kaushik A, Kumar S, Mishra RK (2020) Comparative study on air quality status in Indian and Chinese cities before and during the COVID-19 lockdown period. Air Qual. Atmos Health 13:11671178

Allen GA, Lawrence J, Koutrakis P (1999) Field validation of a semi continuous method for aerosol black carbon (aethalometer) and temporal patterns of summertime hourly black carbon measurements in southwestern PA. Atmos Environ 33:817-823

Anil I, Alagha O (2020) The impact of COVID-19 lockdown on the air quality of Eastern Province, Saudi Arabia. Air Qual Atmos Health 14:117-128. https://doi.org/10.1007/s11869-020-00918-3

Arey J, Atkinson R (2003) Photochemical reactions of PAH in the atmosphere. In: Douben PET (ed) PAHs: an eco toxicological perspective. John Wiley and Sons Ltd, New York, pp 47-63 
Baek SO, Field RA, Goldstone ME, Kirk PW, Lester JN, Perry R (1991) A review of atmospheric polycyclic aromatic hydrocarbons: sources, fate and behavior. Water Air Soil Pollut 60:79-300

Belis CA, Karagulian F, Larsen BR, Hopke PK (2013) Critical review and meta-analysis of ambient particulate matter source apportionment using receptor models in Europe. Atmos Environ 69:94-108

Boeuf B, Fritsch O, Martin-Ortega J (2016) Undermining European environmental policy goals? The EU water framework directive and the politics of exemptions. Water 8:388

Bond TC, Doherty SJ, Fahey DW, Forster PM, Berntsen T, Deangelo BJ, Flanner MG, Ghan S, Karcher B, Koch D, Kinne S, Kondo Y, Quinn PK, Sarofim MC, Schultz MG, Schulz M, Venkataraman C, Zhang H, Zhang S, Bellouin N, Guttikunda SK, Hopke PK, Jacobson MZ, Kaiser JW, Klimont Z, Lohmann U, Schwarz JP, Shindell D, Storelvmo T, Warren SG, Zender CS (2013) Bounding the role of black carbon in the climate system: a scientific assessment. J Geophys Res 118:5380-5552

Briggs NL, Long CM (2016) Critical review of black carbon and elemental carbon source apportionment in Europe and the United States. Atmos Environ 144:409-427

Bull K (2003) Protocol to the 1979 convention on long-range trans boundary air pollution on persistent organic pollutants: The 1998 agreement for the UNECE region, Geneva

Cachier H (1995) Combustion carbonaceous aerosols in the atmosphere: implications for ice core studies. In: Robert JD (ed) Ice core studies of global biogeochemical cycles. NATO ASI Series Springer, Berlin, pp 313-346

CDC. (2020). First travel-related case of 2019 novel coronavirus detected in United States. Chan, J.F.-W., Yuan, S., Kok, K.-H., To, K.K.-W., Chu, H., Yang, J., Xing, F., Liu, J., Yip, C.C.-Y., Poon, R.W.-S., Tsoi, H.-W., Lo, S.K.-F., Chan, K.-H., Poon, V.K.-M., Chan, W.M., Ip, J.D., Cai, J.-P., Cheng, V.C.-C., Chen, H., Hui, C.K.-M., Yuen, K.-Y. (2020). A familial cluster of pneumonia associated with the 2019 novel coronavirus indicating person-to-person transmission: a study of a family cluster. The Lancet 395, 514-523. 79 https://doi.org/10.1016/S0140-6736(20)30154-9

Chan JF, Kok K, Zhu Z, Chu H, To KK, Yuan S, Yuen K (2020) Genomic characterization of the 2019 novel human-pathogenic coronavirus isolated from a patient with atypical pneumonia after visiting Wuhan. Emerging Microbes and Infections 9(1):221-236. $10.1080 / 22221751.2020 .1719902$

Chen SC, Liao CM (2006) Health risk assessment on human exposed to environmental polycyclic aromatic hydrocarbons pollution sources. Sci Total Environ 366:112-123

Chen J, Li C, Ristovski Z, Milic A, Gu Y, Islam MS, Wang S, Hao J, Zhang H, He C, Guo H, Fu H, Miljevic B, Morawska L, Thai P, Lam YF, Pereira G, Ding A, Dumka UC (2017) A review of biomass burning: emissions and impacts on air quality, health and climate in China. Sci Total Environ 579:1000-1034

Cristale J, Silva FS, Zocolo GJ, Marchi MRR (2012) Influence of sugarcane burning on indoor/outdoor PAH air pollution in Brazil. Environ Pollut 169:210-216

De La Torre-Roche RJ, Lee W-Y, Campos-Díaz SI (2009) Soil-borne polycyclic aromatic hydrocarbons in El Paso, Texas: analysis of a potential problem in the United States/ Mexico border region. J Hazard Mater 163:946-958

De Prins S, Dons E, Van Poppel M, Panis L, Van de Mieroop E, Nelen V, Cox B, Nawrot TS, Teughels C, Schoeters G, Koppen G (2014) Airway oxidative stress and inflammation markers in exhaled breath from children are linked with exposure to black carbon. Environ Int 73:440-446

Di-Toro DM, McGrath JA, Hansen DJ (2000) Technical basis for narcotic chemicals and polycyclic aromatic hydrocarbon criteria. I. Water and tissue. Environ Toxicol Chem 19:1951-1970

Favez O, Haddad EII, Piot C, Boreave A, Abidi E, Marchand N, Jaffrezo J-L, Besombes J-L, Personnaz MB, Sciare J, Wortham H, George C,
D'Anna B (2010) Inter-comparison of source apportionment models for the estimation of wood burning aerosols during wintertime in an Alpine city (Grenoble, France). Atmos Chem Phys 10:5295-5314

Florou K, Papanastasiou DK, Pikridas M, Kaltsonoudis C, Louvaris E, Gkatzelis GI, Patoulias D, Mihalopoulos N, Pandis SN (2017) The contribution of wood burning and other pollution sources to wintertime organic aerosol levels in two Greek cities. Atmos Chem Phys 17:3145-3163

Fuller GW, Tremper AH, Baker TD, Yttri KE, Butterfield D (2014) Contribution of wood burning to PM10 in London. Atmos Environ 87:87-94

Gautam S (2020) COVID-19: air pollution remains low as people stay at home. Air Qual. Atmos Health 13:853-857

Grieshop AP, Reynolds CCO, Kandlikar M, Dowlatabadi H (2009) A black-carbon mitigation wedge. Nat. Geosci 2:533-534

Hansen ADA, Rosen H, Novakov T (1984) The aethalometer: an instrument for the real-time measurements of optical absorption by aerosol particles. Sci Total Environ 36:191-196

He C, Li Q, Liou K, Qi L, Tao S, Schwarz JP (2016) Microphysics-based black carbon aging in a global CTM: constraints from HIPPO observations and implications for global black carbon budget. Atmos Chem Phys 16:3077-3098

He C, Liou KN, Takano Y, Zhang R, Zamora ML, Yang P, Li Q, Leung LR (2015) Variation of the radiative properties during black carbon aging: theoretical and experimental inter comparison. Atmos Chem Phys 15:11967-11980. https://doi.org/10.5194/acp-15-11967-2015

Herich H, Hueglin C, Buchmann B (2011) A 2.5 year's source apportionment study of black carbon from wood burning and fossil fuel combustion at urban and rural sites in Switzerland. Atmospheric Measurement Techniques 4:1409-1420

Huang C, Wang Y, Li X, Ren L, Zhao J, Hu Y, Zhang L, Fan G, Xu J, Gu X, Cheng Z, Yu T, Xia J, Wei Y, Wu W, Xie X, Yin W, Li H, Liu M, Xiao Y, Gao H, Guo L, Xie J, Wang G, Jiang R, Gao Z, Jin Q, Wang J, Cao B (2020) Clinical features of patients infected with 2019 novel coronavirus in Wuhan, China. The Lancet 122(395): 497-506. https://doi.org/10.1016/S0140-6736(20)30183-5

Hussain K, Rahman M, Prakash A, Hoque RR (2015) Street dust bound PAHs, carbon and heavy metals in Guwahati city seasonality: toxicity and sources. Sustain Cities Soc 19:17-25

IARC (1984) Polynuclear aromatic compounds. Part 1. Chemical environmental and experimental data IARC monographs on the evaluation of the carcinogenic risk of chemicals to humans, vol. 32 . International Agency for Research on Cancer, Lyon, France

Islam MS, Tusher TR, Roy S, Rahman M (2020) Impacts of nationwide lockdown due to COVID-19 outbreak on air quality in Bangladesh: a spatiotemporal analysis. Air Qual Atmos Health 14:351-363. https://doi.org/10.1007/s11869-020-00940-5

Kelly FJ, Fussell JC (2015) Air pollution and public health: emerging hazards and improved understanding of risk. Environ Geochem Health 37:631-649

Khalizov AF, Xue H, Wang L, Zheng J, Zhang R (2009) Enhanced light absorption and scattering by carbon soot aerosol internally mixed with sulfuric acid. J Phys Chem A 113:1066-1074. https://doi.org/ 10.1021/jp807531n

Kopp RE, Mauzerall DL (2010) Assessing the climatic benefits of black carbon mitigation. Proc Natl Acad Sci 107:11703-11708. https:// doi.org/10.1073/pnas.0909605107

Larsen BR, Gilardoni S, Stenstrom K, Niedzialek J, Jimenez J, Belis CA (2012) Sources for PM air pollution in the Po Plain, Italy: II probabilistic uncertainty characterization and sensitivity analysis of secondary and primary sources. Atmos Environ 50:203-213

Lau KM, Kim MK, Kim KM, Lee WS (2010) Enhanced surface warming and accelerated snow melt in the Himalayas and Tibetan Plateau induced by absorbing aerosols. Environ Res Lett 5:025204 
Li Q et al (2020) Early transmission dynamics in Wuhan, China, of novel coronavirus-infected pneumonia. N. Engl. J. Med. https://doi.org/ 10.1056/NEJMoa2001316

Liu Y, Liu L, Lin JM, Tang N, Hayakawa K (2006) Distribution and characterization of polycyclic aromatic hydrocarbon compounds in airborne particulates of East Asia, China. Particuology 4(6):283296

Magalhaes S, Baumgartner J, Weichenthal S (2018) Impacts of exposure to black carbon, elemental carbon, and ultrafine particles from indoor and outdoor sources on blood pressure in adults: a review of epidemiological evidence. Environ Res 161:345-353

Mostert MMR, Ayoko GA, Kokot S (2010) Application of chemometrics to analysis of soil pollutants. TrAC Trends Anal Chem 29:430-435

Muller RA, Muller EA (2013) Air pollution and cigarette equivalence. Berkeley Earth 47

Niranjan R, Thakur AK (2017) The toxicological mechanisms of environmental soot (black carbon) and carbon black: focus on oxidative stress and inflammatory pathways. Front Immunol 8:763

Nisbet ICT, Lagoy PK (1992) Toxic equivalency factors (TEFs) for polycyclic aromatic hydrocarbons (PAHs). Regul Toxicol Pharmacol 16(3):290-300

Oberg, M., Jaakkola, M.S., Prüss-Üstün, A., Schweizer, C., Woodward, A. (2010). Secondhand smoke, assessing the environmental burden of disease at national and local levels, vol. 18. World Health Organization, Geneva, environmental burden of disease series. http://www.who.int/quantifying_ehimpacts/publications/SHS.Pdf.॥

Ohara T, Akimoto H, Kurokawa J, Horii N, Yamaji K, Yan X, Hayasaka $\mathrm{T}$ (2007) An Asian emission inventory of anthropogenic emission sources for the period 1980-2020. Atmos Chem Phys 7:4419-4444. https://doi.org/10.5194/acp-7-4419-2007

Panda S, Mallik C, Nath J, Das T, Ramasamy B (2020) A study on variation of atmospheric pollutants over Bhubaneswar during imposition of nationwide lockdown in India for the COVID-19 pandemic. Air Qual Atmos Health 14:97-108. https://doi.org/10.1007/ s11869-020-00916-5

Pani SK, Wang SH, Lin NH, Chantara S, Lee CT, Thepnuan D (2020) Black carbon over an urban atmosphere in northern peninsular Southeast Asia: characteristics, source apportionment, and associated health risks. Environ Pollut 259(2020):113871

Peng C, Chen WP, Liao XL, Wang ME, Ouyang ZY, Jiao WT, Bai Y (2011) Polycyclic aromatic hydrocarbons in urban soils of Beijing: status, sources, distribution and potential risk. Environ Pollut 159: 802-808

Petzold A, Ogren JA, Fiebig M, Laj P, Li SM, Baltensperger U, HolzerPopp T, Kinne S, Pappalardo G, Sugimoto N, Wehrli C, Wiedensohler A, Zhang XY (2013) Recommendations for reporting "black carbon" measurements. Atmos Chem Phys 13:8365-8379

Pies C, Hoffmann B, Petrowsky J, Yang Y, Ternes TA, Hofmann T (2008) Characterization and source identification of polycyclic aromatic hydrocarbons (PAHs) in riverbank soils. Chemosphere 72: 1594-1601

Ramanathan V, Carmichael G (2008) Global and regional climate changes due to black carbon. Nat Geosci 1:221-227

Rastogi N, Singh A, Sarin MM, Singh D (2016) Temporal variability of primary and secondary aerosols over northern India: impact of biomass burning emissions. Atmos Environ 125:396-403

Ravindra K, Sokhi R, Van Grieken R (2008) Atmospheric polycyclic aromatic hydrocarbons: source attribution, emission factors and regulation. Atmos Environ 42:2895-2921

Rothman KJ, Greenland S, Lash TL (2008) Modern Epidemiology. Wolters Kluwer/Lippincott Williams \& Wilkins, Philadelphia, pp 53-77

Rupakheti D, Adhikary B, Praveen PS, Rupakheti M, Kang S, Mahata KS, Naja M, Zhang Q, Panday AK, Lawrence MG (2017) Premonsoon air quality over Lumbini, a world heritage site along the Himalayan foothills. Atmos Chem Phys 17:11041-11063
SAFAR (System for Air Quality Forecasting and Research). (2010). A special report emission inventory for National Capital Region Delhi Ministry of Earth Sciences. Government of India (http://safar. tropmet.res.in)

Saglietto A, D'Ascenzo F, Zoccai GB, De Ferrari GM (2020) COVID-19 in Europe: the Italian lesson. Lancet 395:1110-1111

Sciare J, D'Argouges O, Sarda-Esteve R, Gaimoz C, Dolgorouky C, Bonnaire N, Favez O, Bonsang B, Gros V (2011) Large contribution of water-insoluble secondary organic aerosols in the region of Paris (France) during wintertime. J Geophys Res 116:D22203

Sharma M, Jain S, Lamba BY (2020) Epigrammatic study on the effect of lockdown amid Covid-19 pandemic on air quality of most polluted cities of Rajasthan (India). Air Qual. Atmos Health 13:1157-1165

Singh RP, Chauhan A (2020) Impact of lockdown on air quality in India during COVID-19 pandemic. Air Qual. Atmos Health 13:921-928

Srivastava AK, Singh S, Pant P, Dumka UC (2012) Characteristics of black carbon over Delhi and Manora peak - a comparative study. Atmos. Sci. Lett 13:223-230. https://doi.org/10.1002/asl.386

Streets DG, Yarber KF, Woo JH, Carmichael GR (2003) Biomass burning in Asia: annual and seasonal estimates and atmospheric emissions. Global Biogeochem Cy 17(4):1099

Thepnuan D, Chantara S, Lee CT, Lin NH, Tsai YI (2019) Molecular markers for biomass burning associated with the characterization of $\mathrm{PM}_{2.5}$ and component sources during dry season haze episodes in Upper South East Asia. Sci. Total Environ 658:708-722

Tobiszewski M, Namieśnik J (2012) PAH diagnostic ratios for the identification of pollution emission sources. Environ Pollut 162:110 119

U.S. EPA. (1991). Risk assessment guidance for superfund, volume 1, human health evaluation manual (part B, development of risk-based preliminary remediation goals). OSWER; 1991 [9285.7-01B. EPA/ 540/R-92/003]

United States Environmental Protection Agency. (1989). Risk assessment guidance for superfund. vol. I. USEPA, Washington (Human health evaluation manual (part A). EPA 540-1-89-002, Office of Emergency and Remedial Response)

Vadrevu KP, Lasko K, Giglio L, Justice C (2015) Vegetation fires, absorbing aerosols and smoke plume characteristics in diverse biomass burning regions of Asia. Environ Res Lett 10:105003. https://doi. org/10.1088/1748-9326/10/110/105003

Van der Zee SC, Fischer PH, Hoek G (2016) Air pollution in perspective: health risks of air pollution expressed in equivalent numbers of passively smoked cigarettes. Environ Res 148:475-483

Venkataraman C, Lyons JM, Friedlander SK (1994) Size distributions of polycyclic aromatic hydrocarbons and elemental carbon. 1. Sampling, measurement methods, and source characterization. Environmental Science \& Technology 28:555-562

Venkataraman C, Habib G, Kadamba D, Shrivastava M, Leon JF, Crouzille B, Boucher O, Streets DG (2006) Emissions from open biomass burning in India: integrating the inventory approach with high resolution moderate resolution imaging spectroradiometer (MODIS) active-fire and land cover data. Glob Biogeochem Cycles 20:GB2013. https://doi.org/10.1029/2005GB002547

Wang Z, Li K, Lambert P, Yang C (2007) Identification, characterization and quantitation of pyrogenic polycyclic aromatic hydrocarbons and other organic compounds in tire fire products. J Chromatogr A 1139(1):14-26

Wang Y, Hopke PK, Utell MJ (2011) Urban-scale spatial-temporal variability of black carbon and winter residential wood combustion particles. Aerosol Air Qual Res 11:473-481

Weingartner E, Saathoff H, Schnaiter M, Streit N, Bitnar B, Baltensperger U (2003) Absorption of light by soot particles, determination of the absorption coefficient by means of aethalometers. J Aerosol Sci 34: 1445-1463 
WHO (World Health Organization). (2003). Health aspects of air pollution with particulate matter, ozone and nitrogen dioxide. http:// www.euro.who.int/document/e79097

WHO (World Health Organization)? (2014). Burden of disease from air pollution. http://www.who.int/phe/health topics/outdoorair/ databases/FINAL_HAP_AAP_BoD_24March2014.pdf, 02.02.16

Wolff GT (1981) Particulate elemental carbon in the atmosphere. J Air Pollut Control Assoc 31(9):935-938

World Health Organization. (2020a). Novel coronavirus - Thailand (exChina)

World Health Organization. (2020b). Novel coronavirus - Japan (exChina)

Wu J, Lu J, Min X, Zhang Z (2018) Distribution and health risks of aerosol black carbon in a representative city of the Qinghai-Tibet Plateau. Environ Sci Pollut Res 25(20):19403-19412

Wu F, Zhao S, Yu B, Chen Y-M, Wang W, Song Z-G, Zhang Y-Z (2020) A new coronavirus associated with human respiratory disease in China. Nature 579(7798):265-269. https://doi.org/10.1038/ s41586-020-2008-3

Xu S, Liu W, Tao S (2006) Emission of polycyclic aromatic hydrocarbons in China. Environmental Science \& Technology 40:702-708

Yang X, Okada Y, Tang N, Matsunaga S, Tamura K, Lin J, Kameda T, Toriba A, Hayakawa K (2007) Long-range transport of polycyclic aromatic hydrocarbons from China to Japan. Atmos Environ 41: $2710-2718$

Yu Y, Guo H, Liu Y, Huang K, Wang Z, Zhan X (2008) Mixed uncertainty analysis of polycyclic aromatic hydrocarbon inhalation and risk assessment in ambient air of Beijing. J Environ Sci 20:505-512
Yunker M, MacDonald R, Vingarzan R, Mitchell R, Goyette D, Sylvester S (2002) PAHs in the Fraser River basin: a critical appraisal of PAH ratios as indicators of PAH source and composition. Org Geochem 33:489-515

Zhang YX, Tao S (2008) Emission of polycyclic aromatic hydrocarbons (PAHs) from indoor straw burning and emission inventory updating in China. Ann N Y Acad Sci 1140:218-227

Zhang R, Khalizov AF, Pagels J, Zhang D, Xue H, Mcmurry PH (2008) Variability in morphology, hygroscopicity, and optical properties of soot aerosols during atmospheric processing. P Natl Acad Sci USA 105:10291-10296

Zhang YL, Huang RJ, El Haddad I, Ho KF, Cao JJ, Han Y, Zotter P, Bozzetti C, Daellenbach KR, Canonaco F, Slowik JG, Salazar G, Schwikowski M, Schnelle-Kreis J, Abbaszade G, Zimmermann R, Baltensperger U, Prevot ASH, Szidat S (2015) Fossil vs. non-fossil sources of fine carbonaceous aerosols in four Chinese cities during the extreme winter haze episode of 2013. Atmos Chem Phys 15: $1299-1312$

Zotter P, Herich H, Gysel M, El-Haddad I, Zhang Y, Mocnik G, Hüglin C, Baltensperger U, Szidat S, Prevot ASH (2017) Evaluation of the absorption Ångstr€om exponents for traffic and wood burning in the Aethalometer-based source apportionment using radiocarbon measurements of ambient aerosol. Atmos Chem Phys 17:4229-4249

Publisher's note Springer Nature remains neutral with regard to jurisdictional claims in published maps and institutional affiliations. 